\title{
An Evaluation of Malaysia's Political Leadership in Malaysia-US Relations in the Post 9/11 Era
}

\author{
Mas Juliana Mukhtaruddin \\ School of International Studies \\ Universiti Utara Malaysia \\ mas@uum.edu.my
}

DOI: https://doi.org/10.32890/jis2015.11.9

\begin{abstract}
The 9/11 attacks perpetrated against the United States has impacted Malaysia-US relations in a significant way. Despite the murmurs of disapproval and condemnation from the international community that characterised the controversial US invasion of Iraq in 2003, Malaysia-US relations have grown from strength to strength. It is suggested that Malaysia's political leadership is one of the contributing factors that has shaped the growing bilateral relationship. Hence, the purpose of this paper is to examine the role played by Malaysia's political establishment in nurturing the progressive relations between the two countries. Certainly, both Malaysia and the US exist in a dynamic global world that is constantly shaped by events that take place within their surrounding environment.
\end{abstract}

Keywords: Malaysia, United States, Post 9/11, political leadership, bilateral relations.

\section{Introduction}

The relationships between actors in the international system were significantly changed in the aftermath of September 11, 2001 incident (9/11 hereafter). Despite the unfortunate event that took place more than a decade ago, its impact is still felt in many countries. Other major incidents that occurred after 9/11, namely the War in Afghanistan (2001) and the Iraq War (2003), have to some degree impacted the relations between the West and the Muslim world. Hence, the 9/11 was indeed a historic tragedy. After all, the after-effects of 9/11 centred on the fear of terrorism which is believed to originate from Muslim states.

In fact, the West and the Muslim world confront many challenges in their relationship. The repercussions of 9/11 incident significantly affected the relationship and has created a growing gap between the US and the Muslim world. As a result, American involvement in the Afghanistan and Iraq wars had led to destructive responses. On the other hand, despite the 9/11 incident, Malaysia-US relations have become much closer ever since. Malaysia as a moderate Muslim country has presented a positive and progressive image of itself to the US and the western world that demonstrate the fact that Islam is a peaceful. 
Even though the ties between Malaysia and the US is often reckoned as a relationship between a major power and a small Muslim nation, the countries' bilateral relations are for various reasons crucial internationally as well as domestically. Importantly, US under Obama's administration has become a 'pivot to Asia policy and has demonstrated a renewed and enhanced commitment to engage countries in Asia-Pacific, including Malaysia' (Kuik 2012). The post $9 / 11$ world has seen significant changes in the way nation-states interact with each other.

Political leadership is an essential element in any bilateral relationship. In post $9 / 11$, Malaysia's political leadership has pursued a progressive political relationship with the US. The role of the leaders is crucial in boosting the existing bilateral ties. With the ascension of Najib Razak and Barrack Obama into power in Malaysia and US, respectively, this has moved Malaysia-US relations to new heights. In fact, Obama was the first American president to visit Malaysia in almost 50 years (U.S. Commission on International Religious Freedom 2015). He made an official visit to Malaysia in April 2014 with the aim of transforming the bilateral relations into strategic relations.

This focal roles and influences of states' leaders have no doubt significantly contributed to the maturation of the bilateral ties (Heng, 2014). This paper, therefore, will focus on the role of the Malaysian political leadership in developing strong relations between the two nations. To this end, an attempt is made to analyse the Malaysian political leaders' post 9/11 styles and postures vis-à-vis the United States. As a result, the discussion is centred around Malaysia's three prime ministers in that period, namely, Dr Mahathir, Badawi and Najib.

\section{Malaysian Political Leadership In Relation to the United States in the Post 9/11 Era}

Indeed the 9/11 incident was tragic to America and many countries in the world. But sometimes tragedy can also yield closer inter-state relations. According to Mohd Azahari (2009) the 9/11 incident has had positive effects on Malaysia-US relations. It is suggested that Malaysia was able to react to this issue in a positive manner. Before $9 / 11$, the MalaysiaUS bilateral ties had its ups and downs. However, after 9/11, Malaysian leadership demonstrated a strong and robust commitment towards the United States, particularly through its support in combating terrorism. He further stressed that this was the first instance of direct co-operation between Malaysia and the United States, thus a positive step. Several significant engagements were undertaken by the Malaysian leaders, such as the setup of the Southeast Asia Regional Centre for Counter-Terrorism (SEARCCT), a centre for antiterrorism training, exchange of information, implementation of the US Customs Service's Container Security Initiative (CSI) at the Klang Port and Tanjung Pelepas Port, and others. These cooperation between the two countries had further solidified their relationship.

Since 9/11, Malaysia's political leadership has placed a high priority on creating a positive and vigorous political relationship. Bettina A. Malone (2010), Press and Information Officer US Embassy in Kuala Lumpur has stated that it is important to look at the administrations 
of Mahathir, Abdullah Badawi and Najib Tun Razak - because 'each one administration governing Malaysia has had a different style and different approach towards their relation with the United States.' Since 2001 there have been three political leaders in Malaysia: Mahathir Mohamad (1981-2003), Abdullah Badawi (2003-2009), and Najib Tun Abdul Razak (2009-present). The following discussion focuses on these three Malaysian premiers and their contributions in managing Malaysia-US relations in the post 9/11 era.

\section{Mahathir Mohamad (Prime Minister of Malaysia, 1981-2003)}

Mahathir Mohamad was the longest serving Prime Minister in Malaysian history with 22 years in office, the last three after the 9/11 incident. During Mahathir administration, Malaysia-US ties experienced ups and downs, indicating the ambivalence of the bilateral relations. Mahathir was critical of the US on many issues both domestic and international, such as the wars in Iraq and Afghanistan, the Israel-Palestinian conflict, the Asian financial crisis and US interference in the removal of Anwar Ibrahim from office as Deputy Prime Minister of Malaysia. However, Mahathir also strongly felt that the events of 9/11 provided an opportunity to strengthen bilateral relations between Malaysia and the US and bring them into a closer relationship. For example, under his leadership Malaysia worked to curb terrorists in the South-East Asian region, eventually leading to the capture one of the important al Qaeda member and a leader of Jemaah Islamiyah, Riduan Isamuddin, a.k.a Hambali in Ayutthaya, Thailand on August 11, 2003 (Philip 2013).

According to Mahathir (2009), Malaysia and the US are both democratic countries, although Malaysia is a parliamentary democracy while the US is a representative democracy. Hence, the foundations of their political ideologies are consistent but the implementation and practices differ in terms of their philosophy. Mahathir Mohamad, Malaysia's fourth prime minister asserted his authoritative power and played two major roles in Malaysia, serving as Prime Minister as well as foreign policy "mastermind" of the country, though he never himself served as Minister of Foreign Affairs. During Mahathir's premiership there were three Foreign Ministers, namely Ahmad Rithaudeen, Ghazali Shafie and Abdullah Badawi. According to Malaysian political analyst Chandra Muzaffar (2009), 'Mahathir is .... very skilful strategist when it comes to international relations.' Although Abdullah Badawi was actually Minister of Foreign Affairs for eight or nine years, it was obvious that the one who was making the foreign policy was Mahathir. Malaysia-US relations prior to 9/11 were seen as ambivalent or uncertain (Ahmad Ghazali 2009). Although there were various avenues of cooperation and engagement between the two countries, there were also tensions as Mahathir was vocal and blunt in voicing his criticism of American foreign policy, especially with regard to the war in Iraq and US interference in Malaysia internal affairs.

Two crucial incidents during Mahathir leadership exemplify this. The first, in 19971998, was the Asian financial crisis which struck Malaysia, and the second was the arrest of Deputy Prime Minister Anwar Ibrahim in 1998. In the first case, Mahathir and the 
Malaysian government refused to seek assistance from the International Monetary Fund (IMF) to resolve Malaysia's financial problems. Mahathir strongly believed that Malaysian economic and financial problems could be resolved through a robust economic recovery and not through seeking aid from the International Monetary Fund (IMF).

In the case of Anwar Ibrahim, Malaysia expressed disappointment with the US interference in its domestic affairs. In 1998 APEC Business Summit dinner, Vice President Al Gore openly criticized the Malaysian government when he said, 'Democracies have done better in coping with economic crises than nations where freedom is suppressed.' He further stressed, 'Democracy confers a stamp of legitimacy that reforms must have in order to be effective' (Landler 1998). Mahathir considered Al Gore's speech as 'one of the most illmannered speeches ever delivered by a leader of a sophisticated, modern nation....' Clearly, the prime minister was outraged by Al Gore's statement. He expressed his regret in his book - 'A Doctor in the House', '...Gore urged Malaysians to overthrow their government right in front of me' (Mahathir 2011, p. 615). With regard to this Chandra Muzaffar (2009) said that 'it was wrong of Vice President Al Gore to make the statement...because it was against the Malaysian Government and in international diplomacy when you are a guest, you don't openly take the side of a group that is opposed to the government.' However, from the US point of view, the imprisonment of Anwar Ibrahim was a violation of human rights. However, Mahathir (2009) maintained his stand that US had no authority to contest Malaysia's Internal Security Act (ISA) which allows the government to arrest those who go against the law. This incident has exposed a kind of "love hate relationship" between Malaysia and the US. Both countries acted and reacted in accordance with their national interests. However, because this was an internal matter, Mahathir (2009) asserted that 'Malaysia is not bound by US demands and can make decisions independently.' On the international scene, Malaysia wanted the US to recognize Malaysia as a free country and to respect Malaysia's voice and opinion both regionally and internationally.

Before 9/11, the US viewed Malaysia differently. Although, many American companies had invested in Malaysia, including SEAGATE, INTEL, IBM and others, politically, the US saw Malaysia as 'autocratic, anti-Semitic, a jailor of political opponents and anti-free market' (Dillon 2009). As a result, Mahathir was depicted as being a bad political leader due to his vocal criticism of American policies towards Muslim countries.

Although Mahathir was seen as a vocal and outspoken Muslim leader opposed to some of American policies, the US did respect Mahathir for his strong personality. Rajmah Hussain (2009) Malaysia's ambassador to the US in 2006-2008 said that, 'the US admired him, because Mahathir was able to command respect of the world, especially the western countries, and also because he was able to lead Malaysia to become what it is now.'

This is seen when the Bush administration expressed respect for Malaysia. 'Mahathir's Malaysia rose from the low ebbs of its international image to sit on the pedestal of the model Muslim nation worthy of an ally,' says Karminder Singh Dillon (2009). According 
to Jawhar (2009), after the events of 9/11 Mahathir was among the first world leaders to contact the US and convey sympathy and condolences, and he personally condemned the attack on American soil. In this sense, the 9/11 incident has brought Kuala Lumpur and Washington closer. Not only did Mahathir promptly express his concern for the victims of the incident, the Malaysian government also took a pro-active stance in safeguarding US interests in the country from any subversive or terrorist activities in Malaysia. To this end, Mahathir directed the parties concerned to increase security at the US Embassy, factories owned by US companies, and tourist attraction spots like the Petronas Twin Tower in Kuala Lumpur (Sodhy 2012).

These responses from Mahathir and the Malaysian government led Marie T. Huhtala, the newly appointed US Ambassador to Malaysia, to express that the US government was very pleased and appreciated Malaysia's support of the US in the war on terror. This was followed by Mahathir meeting with President Bush in May 2002 in Washington DC at the invitation of the President. Both leaders agreed that the meeting was a success wherein they deliberated on several bilateral issues including terrorism. Mahathir firmly stressed Malaysia's position in the Middle East problems, especially the Palestine-Israeli Conflict (Sodhy 2012: 14).

Moreover, during Mahathir's tenure as prime minister, Malaysia was engaged in many initiatives in fighting terrorism. The most significant were concerning military and antiterrorism activities. Many diverse strategies and initiatives were undertaken by Malaysia and US to counter terrorism activities. On 1 July 2003 Malaysia opened the Southeast Asia Regional Centre for Counter-Terrorism (SEARCCT) (Heng 2014). At the ceremony, Malaysia's Minister of Foreign Affairs, Syed Hamid Albar outlined the main objectives of this centre as:

'...to train and enhance the capacity of enforcement, security and government officials on counter-terrorism issues in collaboration with established thinktank institutions and international organisations. The Centre also serves to promote Malaysia's perspective on how best to deal with terrorism in particular its comprehensive approach to counter-terrorism. SEARCCT has also utilized various training courses, seminars, workshops, conferences, and forums to discuss and disseminate the urgency to have a multi-pronged and multi-faceted approach in countering terrorism.' (http://www.searcct.gov.my/ about-searcct/introduction)

This is clear evidence that Malaysia was very concerned by what happened on 9/11 Mahathir's response to the incident gained the White House's recognition of Kuala Lumpur. According to Jawhar (2009), Mahathir's position and views on this matter were wellreceived and seen as good and correct decisions. Thus, Mahathir's stance on and response to 9/11 helped bring Malaysia and the US closer in some respects. 


\section{Abdullah Ahmad Badawi (Prime Minister of Malaysia, 2003-2009)}

Malaysia-US relations during Abdullah Badawi's premiership were even warmer and closer. His leadership style and personality greatly promoted Malaysia-US ties to greater heights. Jawhar (2009) has described Abdullah as having vast experience, having been Foreign Affairs Minister for eight years (1991-1999), making him more diplomatic and less critical towards US foreign policy than Mahathir. President Bush acknowledged Abdullah Ahmad Badawi as a good person with a diplomatic charisma and a nice character. Rajmah Hussain (2009), Malaysian Ambassador to the United States, who personally witnessed President Bush praising Abdullah when he said, 'he is a good man' during one of the USMalaysia bilateral meetings.

Clearly, Abdullah Badawi was less anti-American than Mahathir. Mahathir was considered as "aggressive, hard pushing and persevering," with opposing views towards the US policies. On the other hand, Abdullah was less affected by anti-Western views. This was evident in the different political philosophies of the two leaders (Lee Poh Ping 2009). Abdullah was not as vocal as Mahathir especially in dealing with America. As Chandra Muzaffar (2009) said, 'he was not so vocal, because of his personality but our policy still continued. Abdullah retained the principles of Malaysian foreign policies that had been implemented by the former leaders. However, Mahathir (2009) had expressed dissatisfaction with Abdullah's foreign policy towards the US and pointed out why he was not critical of US. Mahathir felt that Abdullah sought recognition as the new prime minister of Malaysia, and supported the United States due to its status as a super power. Mahathir went on to state that although Abdullah's administration made good efforts to strengthen the bilateral ties he was nonetheless less critical about the US. However, Mahathir agreed that different types of leadership would result in different kinds of relationships as evidenced by warmer relations between Kuala Lumpur and Washington during his successor's (Abdullah) tenure. Bilateral relations were clearly warmer and closer than under his predecessor, and his leadership style and personality certainly had a positive impact on Malaysia-US ties.

Furthermore, in advancing the Malaysia-US relations, on July 19, 2004, Abdullah Badawi made an official visit to the US (Storey 2005). During the meeting, he and President George Bush discussed several issues, such as terrorism, the war in Iraq and the Israeli-Palestinian dispute. This was another important juncture in Malaysia-US bilateral relations during Abdullah Badawi's administration. Hence, the Bush administration considered Abdullah as having solid diplomatic skills and a good personality, a man who would not have confronted and criticized American policy publicly. As far as leadership is concerned, Abdullah's leadership style and personality did a great deal to foster warmer and closer bilateral relations between Malaysia and the US. President Bush further applauded Abdullah Badawi's administration by stating that, 'Malaysia is an example of a country where frustrations have been channelled in a positive way' and 'I respect Prime Minister Badawi, admire his leadership' (Salmi 2007). 
On the issue of Anwar Ibrahim, Abdullah Badawi's leadership managed to improve the Malaysia-US bilateral relations. Actually, the imprisonment of Anwar Ibrahim on "charges of corruption and sodomy in August 2000" (Storey 2005) got condemnation by the Clinton Administration. On September 2, 2004, Anwar Ibrahim was freed by the Malaysia's highest court after almost six years in jail (Sodhy 2012). On that matter, Storey (2005) has stated that the U.S. State Department described Anwar's freedom 'a victory for the rule of law and judicial process in Malaysia.' This clearly depicted Abdullah Badawi's political leadership and his own way and stance in making domestic and international decisions. Martinez (2005: 209) contended that Abdullah Badawi's leadership style was 'to work quietly but constructively and to focus on putting the house in order, whether at home in Malaysia' or abroad.

With regard to combating terrorism, under Abdullah Badawi, Malaysia took several specific strategies and initiatives (Sodhy 2012: 28). First, in 2003, the Malaysian port of Klang implemented the US Customs Service's Container Security Initiative (CSI) to 'carefully monitor cargo in containers in order to prevent terrorists from smuggling weapons of mass destruction into America.' In 2004 a second Malaysian port, the Port of Tanjung Pelepas in Johor, also implemented CSI.

Later that same year, John Bolton, US Secretary for Arms Control and International Security, visited Malaysia to introduce the Proliferation Security Initiative (PSI) for the purpose of preventing the spread of weapons of mass destruction (Sodhy 2012). Regarding this matter, the US was very concerned with the security of the Straits of Malacca, which they believed might be used by terrorists to accelerate their activities in the region. To counter such threats, the US commenced the Regional Maritime Security Initiative (RMSI) to safeguard the Straits of Malacca from possible terrorist activities related to piracy and trafficking in humans and drugs (Sodhy 2012: 28). Although the US proposed to guard the Straits of Malacca together with the littoral states (Malaysia, Indonesia and Singapore), Malaysia and Indonesia refused to participate in the initiative. Malaysia on the one hand, agreed to work together with the US to combat terrorism, but on the other hand, Malaysia asserted itself as strong and confident enough to protect the Straits of Malacca independent from the US involvement.

In addition, Abdullah Badawi consistently pointed out to the US that it was indeed important to identify the basic source of terrorism. For this reason, he urged the US to sort out the Palestinian nationhood problem (Martinez 2005).Thus, in 2006, the US Department of State Country Reports on Terrorism (as mentioned in Sodhy 2012: 32) praised the Malaysian government under Abdullah Badawi for its support and concern in fighting terrorism in the region. Malaysia had contributed a great deal to this crucial international problem, and the US acknowledged Malaysia as a vital and strong partner in combating terrorism. 


\section{Mohammad Najib Abdul Razak (Prime Minister of Malaysia, 2009 - present)}

Malaysia-US relations under Prime Minister Najib Razak is even much closer than under the previous political leaders. It appears that Najib's educational background contributed to this. According to Jawhar (2009) Najib 'is so Westernized, he mixes very well with people.' He is 'easy-going and open-minded' and this will certainly play an important role in MalaysiaUS relations. Fui K. Soong, Executive Director and Yap Teck Seng, Government Affairs Manager - AMCHAM - American Malaysian Chamber Of Commerce (2009), shared the same opinion as Jawhar, stating that Malaysia-US relations are much better under Najib's administration.

Malaysia-US ties have taken a new turn by the personal relations between Najib Razak and Obama. A 20-minute telephone call conversation between Prime Minister Najib Razak and US President Barack Obama has shown that the US is also interested in boosting the Kuala Lumpur-Washington relationship. As quoted by the National News Agency of Malaysia or Bernama, Najib Razak disclosed what Obama said to him, 'You should be proud of Malaysia as it is a moderate Muslim country, (yet) there exists a harmonious multi-ethnic community' (The Star Online 27.06.2009).

Exchanging visits of the political leaders is another important factor in the progress of Malaysia-US close relations during Najib Razak and Obama tenures. In April 2010, a year after holding the position as Malaysia's Prime Minister, Najib Razak went to the US for the Nuclear Security Summit in Washington. On this occasion, Najib Razak met Obama and this opportunity was perceived as advancement to Malaysia-US bilateral ties. The visit to the US also initiated the avenue for sturdy economic opportunities between the two nations. Mehta (2010) considered the visit of Najib Razak to the US as creating a 'good feeling' and 'business-friendly overtures' to the US business group.

This situation is in part made possible due to Najib's character and personality as an open-minded individual. There have been good indicators from the US Embassy in Kuala Lumpur on the state of Malaysia-US relations. According to Bettina A. Malone, the Press and Information Officer of the US Embassy in Kuala Lumpur, 'Najib is more diplomatic and easy going. This is what the Americans say about him.' Moreover, she stated that, 'the United States feels hopeful because of the warmer trend in the relationship that has taken root in Malaysia, and [anticipates] that more will happen as a result of the warmer trend' (Malone 2010).

After the re-election of Barack Obama as US president in 2012, Prime Minister Najib Razak congratulated him and stated that Malaysia as a moderate Muslim country will continue and that Malaysia stands ready to help the United States as it seeks to better engage with those of the Islamic faith' (The Star Online, 08.11.2012). He further expressed his view of Malaysia's role in willing to act as a bridge between the Muslim and Western worlds: 


\begin{abstract}
'Our moderate model of Islam is a force for good - and it is from having witnessed the benefits of this approach every day that I decided to call for a Global Movement of the Moderates in which all religions should come together in one voice to solve issues that plague the world today' (New Straits Times, 10.07.2012).
\end{abstract}

On another occasion, Obama made a surprise call to Prime Minister Najib Razak to congratulate him on winning Malaysia's general election. To Obama, this victory indicates there is strong and full support from Malaysians based on the capability and competency of Najib and his dynamic administration. According to a statement released by the Prime Minister's office, during the conversation Obama expressed US hope to further enhance this bilateral relation. The statement says that 'Malaysia and the United States will continue to strengthen bilateral relations through regional and international cooperation' (The Star Online 14.05.2013). Such a statement by Malaysia's Prime Minister is another example of enhancing bilateral relationships.

In October 2013, Obama had planned to make an official visit to Malaysia, but unfortunately, it was deferred due to domestic problems in the US government. In any case, Obama made a personal phone call to Najib Razak apologizing to him for the cancellation of his visit but assured him that he remained committed to visiting Malaysia at a later time. Thus, Najib Razak replied that Malaysia comprehended America's domestic crisis condition (Bernama, 02.10.2013).

In keeping with his commitment, Obama finally made formal visits to Japan, South Korea and the Philippines, including Malaysia on April 2014 (Dalphino 2014; Brandon 2014). The main objective of the Obama's visit was to upgrade Malaysia-US relations to a Comprehensive Partnership level. The Comprehensive Partnership is understood as 'a policy umbrella, designed to bring together all aspects of the bilateral relationship: political and diplomatic cooperation; trade and investment; education and people to people ties; security and defense cooperation; and collaboration on the environment, science and technology, and energy' (Dalphino 2014). Hence, the visit was a significant episode in the history of Malaysia-US bilateral ties. According to Munir Majid (2014), 'The most significant achievement of President Obama's successful visit to Malaysia... is the elevation of bilateral relations to a Comprehensive Partnership.'

Mutual relations is essential for fostering robust diplomatic relations. On December 24, 2014, Obama and Najib played golf together the Marine Corps base in Kanehoe Bay, Hawaii an indication of the growing bond between the two leaders. According to Najib Razak, 'Playing golf is not something strange or extraordinary... because during the times of Tun Abdul Razak (Malaysia's second prime minister), Tun Dr Ismail Abdul Rahman (second deputy prime minister), playing golf with world leaders was described as golf diplomacy' (The Star Online 27.12. 2014). Furthermore, the White House reported that, "The two 
leaders took the opportunity to discuss the growing and warming relationship between the United States and Malaysia' (as cited in Nakamura 2014). The president was reported to have said that he is keened to meet Prime Minister Najib in 2015 for the ASEAN Summit.

On November, 2015, President Obama made an official visit to South East Asia region where he attended several important meetings, namely the 2015 Asia-Pacific Economic Cooperation (APEC) Summit in Manila (November 18-19, 2015), the 27th ASEAN Summit (November, 18-22, 2015) including the 3rd ASEAN-US Summit (November 21, 2015) and The 10th East Asia Summit (EAS) (November 21-22, 2015) in Kuala Lumpur. In this respect, Obama for the second times visited Malaysia after his first visit in April 2014. This showed his strong commitment to Malaysia and the rest of the South East Asia region (Syed Azahedi 2015). Prime Minister Najib Razak praised Obama for the second visit to Malaysia during the speech remarks afterward of the bilateral meeting in Kuala Lumpur Convention Centre, Kuala Lumpur on November 20, 2015. He stated that it has been 'a wonderful accomplishment in terms of his commitment not only to Malaysia, but also to the region. And we had a very good discussion on bilateral issues' (The White House, 2015). During this momentous events, Najib Razak and Obama hold a bilateral meeting and discussed on several crucial bilateral issues between the two nations.

They did discusses on, firstly, on issues regarding the violent terrorism particularly in fighting the Islamic State of Iraq and the Levant (ISIL). Malaysia under Najib Razak administration stressed the important of maintaining peace and stability in the international community. He said that 'The Malaysian government is very clear on unequivocally that we are up against IS, against its ideology, what it stands for. It is evil. It is against Islam' (The White House, 2015). For that matter, Malaysia agreed to be the counter-messaging centre as a hub for disseminating the true understanding and teaching of Islam. Najib Razak stated that, 'It is why it's important for us to present the counter-narrative, to present the authentic Islam, the true Islam, so that people realize what IS represents, or tries to represent, is the total perversion of Islam. So that work is important for us, and we will continue to present what we believe is a true picture of Islam (The White House 2015).

Secondly, both Malaysia and the US premiers deliberated on the Trans-Pacific Partnership Agreement (TPPA) as it is very important matter. Obama stressed that TPP 'is more than just a trade pact as it also has important strategic and geopolitical benefits' as well as TPP 'encourages rule of law, and stronger, more effective and more accountable governance' (Noor Soraya 2015). Hence, Najib Razak explained that the TPP issue will be brought to a special session at Parliament in January 2016 (the White House 2015). It will take about two years to process and finalise the agreement on TPP. They also discussed on the issues of the climate change and the South China Sea tension.

Briefly since $9 / 11$, three Malaysian premiers have all been in conformity on establishing robust bilateral relations, and entirely believed that these relationships need to be wellfostered and constantly maintained. The political leadership of Malaysia in the post 9/11 
era certainly demonstrates their intent to develop a more progressive bilateral relationship between the two countries that have been attained in recent years. Kuik (2015:2) affirmed that Malaysia was informed that its relation with the US were 'among the most vital aspects of [its] external policy' and deemed this bilateral relationship to be 'asymmetric'. It is well understood that the US is a major power in the international system, and though small country, Malaysia is widely known as a developing country as well as a moderate Muslim nation.

\section{Conclusion}

After the post 9/11 incident, the three Malaysian administrations are all in agreement about establishing a robust bilateral relationship with the US, and they deem that this bilateral relationship needs to be brought up and continuously upheld. Malaysian political leadership has been one of the primary components in enhancing Malaysia-US relations post 9/11. Essentially, the Malaysian political leaders have maneuvered the bilateral relationship in a progressive course particularly after the $9 / 11$ attacks. Hence, Malaysia under Mahathir Mohamad, Abdullah Badawi and presently, Najib Razak has visibly displayed their dynamism and progressive political leadership in managing Malaysia-US bilateral relations. Many occasions of cooperation and engagement have taken place between the two countries that showcase their strong commitment and partnership in many issues from combating terrorism as well as golf diplomacy. Thus, Malaysia is increasingly been regarded by the US as their close counterpart in combating terrorism as well as an important Muslim partner, acting as a passage to unite the Western nations and the Muslim world. Hence, through its active and charismatic political leaderships, Malaysia despite being a small state in the area has established very strong ties with the US. The fact that the country has received two visits from the US president in a span of two years highlights the growing bond between these two nations.

\section{References}

Ahmad Ghazali Abu Hassan. (2009). Malaysia-US relations post 911: A study of complex interdependence relationship. Interviewed by Mas Juliana Mukhtaruddin [in person] Universiti Pertahanan Malaysia, Kem Sungai Besi, 57000 Kuala Lumpur, May 6, 2009.

Alagappa, M. (2014). Obama's golden opportunity in Malaysia. Carnegie Endowment for International Peace. Retrieved from http://carnegieendowment.org/2014/04/07/ obama-s-golden-opportunity-in-malaysia

Bernama. (2013, October 2). Obama postpones his keenly-awaited visit to Malaysia this month, says Najib. Retrieved from http://www.bernama.com.my/bernama

Brandon, J. (2014). Obama's Asia trip to test rebalancing policy in Asia. Asiafoundation. org.from http://asiafoundation.org/in-asia/2014/04/23/obamas-asia-trip-to-test-rebalancingpolicy 
Chandra Muzaffar. (2009). Malaysia-US relations post 911: a study of complex interdependence relationship. Interviewed by Mas Juliana Mukhtaruddin [in person] Centre for Policy Research and International Studies (CENPRIS), University Sains Malaysia, 11800, USM, Penang, May 5, 2009.

Dalpino, C. (2014). US-Southeast Asia relations: A strong start to the new year. Comparative Connections A Triannual E-Journal on East Asian Bilateral Relations. Retrieved from http://csis.org/files/publication/1401qus_seaasia_1.pdf

Dillon, K. S. (2009). Malaysia-US relations post 911: a study of complex interdependence relationship. Interviewed by Mas Juliana Mukhtaruddin [in person] Ministry Of Defence, Malaysia, Email interview, May 21, 2010.

Fui, K. S. \& Yap, T. S. (2009). Malaysia-US relations post 911: a study of complex interdependence relationship. Interviewed by Mas Juliana Mukhtaruddin [in person] AMCHAM (American Malaysian Chamber of Commerce), 11.03-11.05, Level 11, AMODA, 22, Jalan Imbi, 55100, Kuala Lumpur, November 10, 2009.

Heng, P. (2014). Malaysia and the United States: A maturing partnership. In M. Weiss, Routledge Handbook of Contemporary Malaysia (1st. ed.). London: Routledge.

Jawhar Hassan. (2009). Malaysia-US relations post 911: a study of complex interdependence relationship. Interviewed by Mas Juliana Mukhtaruddin [in person] Institute of Strategic and International Studies (ISIS), Malaysia. No. 1, Persiaran Sultan salahudin, P.O.Box 12424, 50778 Kuala Lumpur, May 7, 2009.

Kuik, C. (2012). Malaysia's U.S. policy under Najib: Ambivalence no more? In RSIS Working Paper. Singapore: S. Rajaratnam School of International Studies.

Kuik, C. (2015). Malaysia's relation with major and middle powers. Asia Centre. Retrieved from http://www.centreasia.eu/sites/default/files/publications_pdf/etude_ malaisie_2015_dgris.pdf

Landler, M. (1998). Gore, in Malaysia, says its leaders suppress freedom. New York Times, 17th November 1998.

Lee, P. P. (2009). Malaysia-US relations post 911: a study of complex interdependence relationship. Interviewed by Mas Juliana Mukhtaruddin [in person] Institute of Malaysian \& International Studies (IKMAS), Universiti Kebangsaan Malaysia (UKM), 43600 UKM Bangi, Selangor Darul Ehsan, May 7, 2009.

Mahathir Mohamad. (2011). A doctor in the house. Petaling Jaya: MPH Pub.

Mahathir Mohamad. (2009). Malaysia-US relations post 911: a study of complex interdependence relationship. Interviewed by Mas Juliana Mukhtaruddin [in person] Perdana Leadership Foundation, NO. 1, Jalan P8H, Precint 8, Putrajaya, November 9, 2009.

Malone, B. (2010). Malaysia-US relations post 911: a study of complex interdependence relationship. Interviewed by Mas Juliana Mukhtaruddin [in person] United States Embassy, 376 Jalan Tun Razak, 50400 Kuala Lumpur, April 10, 2010.

Martinez, P. (2005). Malaysia in 2004: Abdullah Badawi defines his leadership. Southeast Asia Affair. 
Mehta, M. (2010, April 21). Najib's US visit reset tone and tenor of bilateral relations, says expert. Bernama. Retrieved from: http://www.ssig.gov.my/blog/2010/04/21/najibsus-visit-reset-tone-and-tenor-of-bilateral-relations-says-expert/

Mohd. Azahari Abdul Karim. (2009). Malaysia-US relations post 911: a study of complex interdependence relationship. Interviewed by Mas Juliana Mukhtaruddin [in person] Centre for Policy Research and International Studies (CENPRIS), University Sains Malaysia, 11800, USM, Penang May 12, 2009.

Munir Majid. (2014, May 3). US-Malaysia relations going forward. The Star Online. Retrieved from http://www.thestar.com.my/Business/Business-News/2014/05/03/ USMalaysia- relations-going-forward/

Nakamura, D. (2014). In Hawaii, Obama golfs with Malaysian prime minister Najib Razak. The Washington Post. Retrieved from https://www.washingtonpost.com/news/postpolitics/wp/2014/12/24/in-hawaii-obama-golfs-with-malaysian-prime-ministernajib-razak/

New Straits Times. (2012, July 10). PM pays tribute to Malaysia-US strong bonds. Retrieved from http://www.nst.com.my/top-news/pm-pays-tribute-to-malaysia-us-strong-bonds \%201.105560\#.UZTUJEbVLjE.email

Noor Soraya Mohd Jamal. (2015). ASEAN Summit 2015. Asean2015.Bernama.com. Retrieved 24 November 2015, from http://asean2015.bernama.com/newsdetail. php?id=1192160

Philip, M. (2013). Chronicle of Malaysia: Fifty Years of Headline News, 1963-2013 (1st ed.). Kuala Lumpur: Edition Didier Millet.

Rajmah Hussain. (2009). Malaysia-US relations post 911: a study of complexinterdependence relationship. Interviewed by Mas Juliana Mukhtaruddin [in person] Department of International and Strategic Studies, Faculty of Arts and Social Sciences, University of Malaya, November 20, 2009.

Salmy Hashim. (2007, August 31). Malaysian pm very constructive force for region, says Bush. Bernama. Retrieved from http://www.bernama.com/bernama/v3/

Searcct.gov.my. (2014). Official website of Southeast Asia Regional Centre for counterterrorism - introduction. Retrieved from http://www.searcct.gov.my/about-searcct/ introduction

Sodhy, P. (2012). Malaysia-us relations, 2000-2011. Kuala Lumpur, Malaysia: Institute of Strategic and International Studies (ISIS) Malaysia.

Storey, I. (2005). Malaysia and the United States 2004-2005: The Best of Times? Hawaii: Asia-Pacific Center for Security Studies. Retrieved from http://apcss.org/Publications/ SAS/APandtheUS/StoreyMalaysia2.pdf

Syed Azahedi. (2015, November 20). Obama to arrive today. New Straits Times. Retrieved from http://www.nst.com.my/news/2015/11/112550/obama-arrive-today

The Star Online. (2012, November 8). Najib: Obama win augurs well for US-Muslim ties. Retrieved from http://www.thestar.com.my/story/

The Star Online. (2013, May 14). Barack Obama surprises Najib with personal call over GE13 victory. Retrieved from http://www.thestar.com.my/News/Nation/2013/05/14/ Barack-Obama-surprises-Najib-with-personal-call-over-GE13-victory/ 
The Star Online. (2014). Golf game with Obama for diplomatic relations, says NaRetrieved from https://www.washingtonpost.com/news/post-politics/wp/2014/12/24/in-hawaiiobama-golfs-with-malaysian-prime-minister-najib-razak/

The Star Online. (2015, October 27). Obama to visit Malaysia in November for USAsean, East Asia summits. Retrieved from http://www.thestar.com.my/News/ Nation/2015/10/27/Obama-to-visit-Malaysia-in-November/

The White House. (2015). Remarks by President Obama and Prime Minister Najib of Malaysia after bilateral meeting. Retrieved from https://www.whitehouse.gov/ the-press-office/2015/11/20/remarks-president-obama-and-prime-minister-najibmalaysia-after

U.S. Commission on International Religious Freedom. (2015). Annual report of the U.S. commission on international religious freedom. Washington: U.S. Commission on International Religious Freedom. Retrieved from http://www.uscirf.gov 